\title{
A Novel Functional Fruit/Vegetable Beverage for the Elderly: Development and Evaluation of Different Preservation Processes on Functional and Enriched Components and Microorganisms
}

\author{
Juliano De Dea Lindner ${ }^{1}$, Daiane Paggi ${ }^{2}$, Vinícius Duarte Pinto ${ }^{3}$, Douglas Soares ${ }^{4}$, Maressa Danieli Dolzan ${ }^{5}$, \\ Daniele Bevacqua ${ }^{6}$, Gustavo Amadeu Micke ${ }^{7} \&$ José Vladimir Oliveira $^{4}$ \\ ${ }^{1}$ Food Science and Technology Department, Federal University of Santa Catarina, Florianópolis, Brazil \\ ${ }^{2}$ Research and Development Department, Organic Bios, Capinzal, Brazil \\ ${ }^{3}$ Research and Development Department, R\&S Blumos, Campinas, Brazil \\ ${ }^{4}$ Food Engineering Department, Federal University of Santa Catarina, Florianópolis, Brazil \\ ${ }^{5}$ Federal Institute of Santa Catarina, Canoinhas, Brazil \\ ${ }^{6}$ EA-unite UR 1115 PSH, Institut National Recherche Agronomique, Avignon, France \\ ${ }^{7}$ Department of Chemistry, Federal University of Santa Catarina, Florianópolis, Brazil \\ Correspondence: Juliano De Dea Lindner, Federal University of Santa Catarina (UFSC), Agricultural Science \\ Center (CCA), Food Science and Technology Department (CAL), Rodovia Admar Gonzaga, 1346. Itacorubi. \\ Florianópolis, SC, Brazil. Tel: 55-483-721-6183.E-mail: juliano.lindner@ufsc.br
}

Received: April 30, 2017

Accepted: May 24, 2017 Online Published: June 4, 2017

doi:10.5539/jfr.v6n4p17

URL: https://doi.org/10.5539/jfr.v6n4p17

\begin{abstract}
Despite lower energy intakes with age, elderly have higher requirements for several nutrients, making them vulnerable to deficiencies that further aggravate aging chronic conditions. To manage this problem, new food formulations are needed to address the nutritional needs of the worldwide growing aging population. In the present work, we develop an innovative functional fruit/vegetable beverage for the elderly using coconut water, orange juice and carrot juice. The beverage was enriched with vitamin $\mathrm{A}$ and $\mathrm{C}$ and supplemented with omega-3 fatty acids and inulin to provide important nutritional elements to the target consumers of this study. Osmolality classified the beverage as hypertonic. Heat (TT), supercritical carbon dioxide $\left(\mathrm{SC}-\mathrm{CO}_{2}\right)$ and dimethyl dicarbonate (DMDC) treatments were applied as preservation methods, and the responses of the functional and enriched components and enzymes were evaluated. Alicyclobacillus acidoterrestris ATCC 49025 and a surrogate Escherichia coli, ATCC 25922, were inoculated in the beverage to induce spoilage and verify the effectiveness of inactivation processes on the cells. The DMDC process reduced $E$. coli to undetectable levels and exhibited a greater reduction of $A$. acidoterrestris vegetative cells, molds and yeasts. The conditions applied in the process with $\mathrm{SC}-\mathrm{CO}_{2}$ did not show satisfactory results in reducing juice microbiota. Loss of vitamin $\mathrm{C}$ and A was mainly associated with the $\mathrm{SC}-\mathrm{CO}_{2}$ treatment. The beverage received a positive acceptability evaluation among the tasters in the sensory analysis and may be introduced as a new vehicle for the consumption of functional compounds, especially by vegans and/or vegetarians and lactose-intolerant elderly.
\end{abstract}

Keywords: coconut water, dimethyl dicarbonate, microbiological challenge testing, non-dairy beverage, orange juice, supercritical carbon dioxide, carrot juice

\section{Introduction}

Consumers are looking for nutrition that goes beyond the status quo, either in terms of extra nutrition or condition-specific benefits. They desire ready-to-drink (RTD) beverages with "better for you" ingredients and simple "clean" labels, and they seek products with functional benefits and great taste. Beverage companies are meeting new consumer demands by introducing group-specific (e.g., gluten-free, muscle recovery, bone health) beverages. Functional beverages can be specifically targeted to particular sectors of the population, focusing, e.g., on women or the elderly. The increase in the elderly population is a general global trend. The leading worldwide cause of death among the elderly is associated with chronic disease, and there is great potential for the prevention of these diseases through diet (United States Department of Health and Human Services and World 
Health Organization, 2011). Fruit/vegetable-based beverages represent an easy and convenient way of consuming important sources of compounds such as vitamins, phenolics and fibers, so necessary for this group of population.

In spite of the many nutritional properties and bioactive compounds described for coconut water (Yong, $\mathrm{Ge}, \mathrm{Ng}$, \& Tan, 2009), orange juice (Agvan, Akyildiz, \& Akdemir Evremdilek, 2014) and carrot juice (Corona et al., 2016), there are no reports on the state-of-the-art technological development of an orange/carrot functional beverage based on coconut water. Recently, Camargo Prado et al. (2015) reported a closely related topic on the development of an innovative functional beverage using coconut water as the main ingredient and cited its natural hydrating qualities, functional health properties and nutritional benefits.

To commercialize an RTD fruit/vegetable beverage, appropriate preservation process and subsequent storage methods are necessary to guarantee the stability of the nutritional and functional compounds, as fruits and vegetables are susceptible to oxidative, enzymatic or microbial spoilage. Heat treatments are the most widely used preservation method for coconut water (Tan, Cheng, Bhat, Rusul, \& Easa, 2014) and fruit juices (Bilek \& Bayran, 2015), as high temperatures lead to inactivation of microbial and enzymatic activities. However, excessively high process temperatures lead to loss of nutritional and healthy compounds as well as the sensory properties of food (Cappelletti et al., 2015).

Non-thermal food processing technologies for preservation and safety have gained widespread acceptance throughout the food industry (Rawson et al., 2011) but still need to be evaluated for effectiveness in different matrices that have not been wet-tested. Among these technologies, particular attention has been given to the use

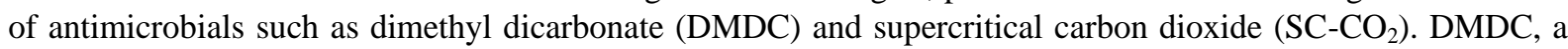
dicarbonic acid ester approved by U.S. FDA (United States Food and Drug Administration, 2001a), is a microbial control agent inhibitor of yeasts used in beverages at a maximum limit of $250 \mathrm{mg} / \mathrm{L}$. Numerous studies have demonstrated that DMDC treatment efficiently causes lethality in many pathogenic microorganisms in fruit juices and has few effects on sensory properties and nutritional value (Yu et al., 2013). High-pressure carbon dioxide (HPCD) process that applies $\mathrm{SC}-\mathrm{CO}_{2}$ is being used to inactivate enzymes and pathogenic microorganisms, resulting in minimal degradation of thermo-labile nutrients and bioactive compounds of foods and preserving sensory and nutritional characteristics (Zhou, Wang, Hu, Wu, \& Liao, 2009). Many studies have demonstrated that HPCD treatment at moderate pressure and temperature can effectively inactivate microorganisms in foods (Damar \& Balaban, 2006).

Microbiological challenge testing continues to be a useful tool for the validation of processes that are intended to deliver some degree of lethality against a target food microorganism. Alicyclobacillus acidoterrestris is an acidothermophilic spore-forming bacterium of great concern to the fruit beverage industry that cause spoilage by producing taint compounds responsible for off-flavors (e.g., 2-methoxyphenol "guaiacol") (Molva \& Baysal, 2015). Thermal resistance studies have demonstrated the ability of this microorganism to survive pasteurization applied to acidic fruit juices (Oteiza, Soto, Alvarenga, Sant'Ana, \& Gianuzzi, 2015). Additionally, pathogens from known foodborne outbreaks should be included in challenge tests to ensure that the formulation and process is sufficiently robust to inhibit those organisms. Pathogenic strains of Escherichia coli were involved in outbreaks linked to the consumption of contaminated unpasteurized fruit juices (Besser et al., 1993). Outbreaks have indicated that low $\mathrm{pH}(<4.0)$ of fruit beverages cannot safeguard against the survival of E. coli O157:H7 (Leyer, Wang, \& Johnson, 1995). Thus, an ideal surrogate E. coli strain applied in the challenge must have, for example, similar thermal and acidic inactivation kinetics as pathogenic E. coli strains (U.S. FDA, 2001b).

In this context, the present study was performed to develop an innovative functional fruit/vegetable beverage using coconut water as the main ingredient. Preservation processes were tested in order to correlate losses in nutritional ingredients with the treatments. The beverage was inoculated with A. acidoterrestris and nonpathogenic $E$. coli to induce spoilage and to verify the effectiveness of inactivation processes on the cells using microbial challenge testing criteria. Although the formulation of juices has been widely explored, the developed beverage can be introduced as a new nutritional vehicle for the consumption of functional and enriched components, especially by vegans and/or vegetarians and lactose-intolerant elderly.

\section{Method}

The fruit/vegetable beverage was produced for this study to evaluate the relationship between its chemical, physicochemical, functional composition and its sensory acceptance after three different preservation processing technologies. To evaluate the effectiveness of the treatments, the beverage was microbiologically challenged. 


\subsection{Extraction of Raw Materials and Beverage Formulation}

Green coconuts (Cocos nucifera L. var. nana) between 6 and 8 months of age and oranges (Citrus $x$ sinensis var. bahia) and carrots (Daucus carota subsp. sativus) at commercial maturity were purchased at the local market in Florianópolis (SC, Brazil). The coconut water, orange juice and carrot juice used in this work were extracted after the fruits were brushed and washed with water containing $100 \mathrm{ppm}$ active chlorine. The coconut water and fresh-squeezed juices were homogenized, filtered under vacuum using filter paper (Whatman, UK) and maintained at $-20^{\circ} \mathrm{C}$ to prevent any microbial or enzymatic activity.

The fruit/vegetable beverage formulation was previously developed after pre-trials using not structured sensory tests (data not shown), and production was carried out at the Federal University of Santa Catarina (UFSC), Food Science and Technology Department Pilot Plant. The formulation was composed of $48 \%$ (w/v) coconut water, $40 \%$ $(\mathrm{w} / \mathrm{v})$ orange juice and $10 \%(\mathrm{w} / \mathrm{v})$ carrot juice. Enriched and functional ingredients (vitamins A and C, omega-3 fatty acids and inulin) were added in the amount necessary to achieve, in the final formulation, $100 \%$ of the RDI (Recommended Daily Intake for adults) in Brazil (Brasil, 2005; Brasil, 2008). In total, forty-five mg of vitamin $\mathrm{C}$ as ascorbic acid (SweetMix, São Paulo, Brazil), $600 \mu \mathrm{g}$ of vitamin A as retinyl acetate (M. Cassab, São Paulo, Brazil), $1.5 \mathrm{~g}$ of an omega-3 mixture from natural fish oil concentrate with EPA (10\%) and DHA (8\%) (Vana-Sana EPA/DHA 10/8 ES, FrieslandCampina Kievit, Meppel, the Netherlands) and $1.5 \mathrm{~g}$ of inulin as soluble fiber from the chicory root (Cargill, São Paulo, Brazil) were added to compose a dose. After weighing and mixing the components in a tank under agitation $(600 \mathrm{rpm})$ for $10 \mathrm{~min}$, the $\mathrm{pH}$ of the beverage was adjusted to 3.50 (HI9321 pH meter, Hanna Instruments, São Paulo, Brazil) with citric acid (Cargill, São Paulo, Brazil), and total soluble solid content was determined directly using a digital refractometer (PR-101, ATAGO, Tokyo, Japan) at $25^{\circ} \mathrm{C}$, resulting in $8.30^{\circ}$ brix. The beverage was degassed under vacuum (-0.65 mbar) and bottled in 250 -ml glass bottles previously sanitized by immersion in peracetic acid solution (1800 ppm) for $10 \mathrm{~min}$. After filling, the headspace was flushed with $\mathrm{N}_{2}$ flux at 1 bar, and the bottles were sealed with sanitized metallic caps and stored at $4{ }^{\circ} \mathrm{C}$ in total darkness.

\subsection{Preservation Processing Technologies}

The analyses performed in this work were carried out on fresh untreated matrix (F) and thermally (TT), supercritical carbon dioxide $\left(\mathrm{SC}-\mathrm{CO}_{2}\right)$ - and dimethyl dicarbonate (DMDC)-treated beverages.

\subsubsection{Thermal Treatment (TT)}

Heat pasteurization equipment consisted of a water bath (Dubnoff Bath TE-0532, Tecnal, Piracicaba, Brazil) with agitation into which $250-\mathrm{mL}$ bottles of beverage were placed. The pasteurization was performed at $85{ }^{\circ} \mathrm{C}$ for $5 \mathrm{~min}$. The process conditions were chosen based on Cappelletti et al. (2015). After treatment, the bottles were cooled and exhausted in an ice water bath and subsequently stored at $4{ }^{\circ} \mathrm{C}$.

\subsubsection{Supercritical Carbon Dioxide Treatment $\left(\mathrm{SC}-\mathrm{CO}_{2}\right)$}

Treatment was conducted employing the static-synthetic method in a high-pressure variable-volume reactor as described by Silva et al. (2013). The experimental setup consisted of a variable-volume reactor with a maximum internal volume of $27 \mathrm{~mL}$, two sapphire windows for visual observation, an absolute pressure transducer (Smar LD301) with a precision of $\sim 0.03 \mathrm{MPa}$, a portable programmer (Smar HT201) for pressure data acquisition and a syringe pump (ISCO 260D). The reactor contained a movable piston that permits pressure control inside the cell without allowing exchange of fluids.

Initially, an amount of $15 \mathrm{~mL}$ of beverage was loaded into the cell with help of a sterile syringe. The juice/ $\mathrm{CO}_{2}$ mass ratio was 1:08. The charge of $\mathrm{CO}_{2}$ was performed with the help of the syringe pump. Then, the cell content was kept at continuous agitation with the help of a magnetic stirrer and a Teflon-coated stirring bar. A metallic jacket surrounds the cell and water from a thermostatic bath was used as heating fluid, which flows through the jacket, so that the cell was kept at the temperature of $33{ }^{\circ} \mathrm{C}$. The pressure system was increased at pressurization rate of $10 \mathrm{MPa} / \mathrm{min}$ using $\mathrm{CO}_{2}$ as pressurizing fluid from its vapor pressure at room temperature ( $\left.\sim 5 \mathrm{MPa}\right)$ up to $8 \mathrm{MPa}$, which was considered the initial working pressure. At this point the system was hold for a short period $(\sim 1 \mathrm{~min})$ to allow system stabilization, and then the pressure was increased until $20 \mathrm{MPa}$. After the procedure, the system pressure was reduced to $8 \mathrm{MPa}$ at the rate of depressurization pre-established. At the end of this process the pressure was manually reduced from $8 \mathrm{MPa}$ to atmosphere pressure. All runs were conducted using one pressure cycle for 120 min (Fig. 1). 


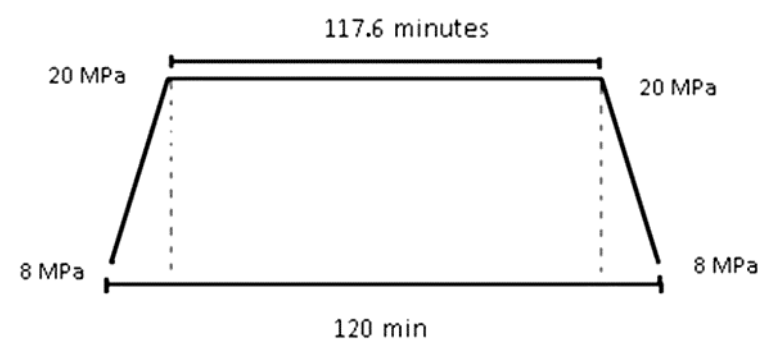

Figure 1. Supercritical carbon dioxide $\left(\mathrm{SC}-\mathrm{CO}_{2}\right)$ treatment conditions adopted, shown in terms of time and pressure

\subsubsection{Dimethyl Dicarbonate Treatment (DMDC)}

The beverage was vigorously mixed in bottles by inversion for $2 \mathrm{~min}$ after the addition of $200 \mu \mathrm{L} / \mathrm{L}$ DMDC (Velcorin, Lanxess, Cologne, Germany) and kept for $4 \mathrm{~h}$ at $25{ }^{\circ} \mathrm{C}$. The bottles were cooled and maintained at $4{ }^{\circ} \mathrm{C}$ until analysis. The final concentration of DMDC added to the beverage was $250 \mathrm{mg} / \mathrm{L}$.

\subsection{Assessment of Composition and Physicochemical Properties of the F Matrix and TT Beverage}

The following analyses were performed to characterize the F matrix and TT beverage.

\subsubsection{Physicochemical}

The $\mathrm{pH}$ was measured directly using a model HI9321 pH meter (Hanna Instruments, São Paulo, Brazil). Acidity was measured by titrimetric analysis using the TT beverage diluted 1:50 (v/v) in distilled water. The diluted solution was neutralized with $0.1 \mathrm{M} \mathrm{NaOH}$ (Merck, Germany) using an alcoholic solution of phenolphthalein (1 $\% \mathrm{v} / \mathrm{v}$ ) as an indicator. Total soluble solids content was determined directly using a digital refractometer (PR-101, ATAGO, Tokyo, Japan) at $25{ }^{\circ} \mathrm{C}$. The concentration of reducing sugars was measured using the 3, 5-dinitrosalicylic acid (DNS) method (Miller, 1959), and total sugar content was measured using acid hydrolysis (Association of Official Analytical Chemistry, 2000). The protein content was determined according to Lowry, Rosebrough, Farr and Randall (1951).

\subsubsection{Antioxidant Activity}

The F and TT samples were analyzed for antioxidant activity (free radical scavenging capacity), which was examined by the reduction of the 1,1-diphenyl-2-picrylhydrazyl radical (DPPH) as described by Ramadan, Kroh and Moersel (2003) with modifications. Five $\mathrm{mL}$ of a $20 \mathrm{mg} / \mathrm{mL}$ DPPH solution in methanol were added to $5 \mathrm{~mL}$ of a methanolic solution of the beverage $(1: 10, \mathrm{v} / \mathrm{v})$. Absorbance was determined spectrophotometrically (UV-1601PC Spectrophotometer, Shimadzu, Japan) at $517 \mathrm{~nm}$ after $30 \mathrm{~min}$, and scavenging activity was calculated as the percent radical reduction. The percent inhibition was defined as [(A517 blank - A517 sample) A517 blank-1]·100-1 (\%). Ascorbic acid was used as a reference component. The analysis was performed in triplicate, and the standard deviation of the mean values was calculated.

\subsubsection{Total Phenolic Content}

The Folin-Ciocalteu method (Singleton \& Rossi, 1965) was used with some modifications to quantify total phenolic compounds using a gallic acid calibration curve $(0$ to $500 \mathrm{mg} / \mathrm{L})$. A total of three hundred $\mu$ l of diluted F matrix and TT beverage in a ratio of $1: 100$ with methanol:water $(6: 4)$ was mixed with $1.5 \mathrm{~mL}$ of 10-fold-diluted Folin-Ciocalteu's phenol reagent and $1.2 \mathrm{~mL}$ of $0.1 \mathrm{M}$ sodium carbonate solution. The mixture was maintained in the dark for $90 \mathrm{~min}$ at $25^{\circ} \mathrm{C}$ before absorbance was measured at $760 \mathrm{~nm}$ using a UV-1601PC spectrophotometer (Shimadzu, Japan). Dilutions were performed in triplicate, and the results are expressed as $\mathrm{mg}$ of gallic acid equivalents (GAE)/L of sample.

\subsubsection{Omega 3 Fatty Acid}

The total lipid content of the F matrix and TT beverage was determined by extracting with organic solvent in a Soxhlet extractor (Tecnal Equip., Piracicaba, Brazil) (AOAC, 2005). The samples had been previously homogenized and subjected to acid hydrolysis with $8 \mathrm{M} \mathrm{HCl}$. From the extract obtained in the determination of total lipids, esterification of fatty acids was performed according to a procedure developed by Hartman and Lago (1973). The methyl esters of the fatty acids were determined by gas chromatography with a flame ionization detector (GC-FID) (GC-2014, Shimadzu, Kyoto, Japan) using an Rtx-2330 fused silica capillary column (105 m, 
$0.25 \mathrm{~mm}$ i.d., $0.20 \mu \mathrm{m}$ film thick, Restek Corp., Bellefonte, PA, USA). The operating conditions were: initial temperature of the column, $140{ }^{\circ} \mathrm{C}$ for $5 \mathrm{~min}$; increasing to $240{ }^{\circ} \mathrm{C}$ at a rate of $2.5{ }^{\circ} \mathrm{C} / \mathrm{min}$; and remaining at $240{ }^{\circ} \mathrm{C}$ for $15 \mathrm{~min}$. The detector was isothermally maintained at $260^{\circ} \mathrm{C}$. The fatty acids were identified using GC Solution software (Shimadzu, Kyoto, Japan) by comparing retention times with those of standards (F.A.M.E. Mix C4-C24, Supelco Analytical, Bellefonte, PA, USA). Nitrogen was used as the carrier gas at a flow rate of 26 $\mathrm{mL} / \mathrm{min}$ with a split ratio of $20: 1$.

\subsubsection{Osmolality}

The osmolality of the TT beverage was determined according to Henriques and Rosado (1999). The freezing point of the sample was measured using a cryoscope (MK 540L, ITR, Esteio, RS, Brazil) and the following equation was applied to determine the osmolality: molal concentration of the sample $=\Delta \mathrm{tc} / \mathrm{Kc}$, where $\Delta \mathrm{tc}$ is the cryoscopic decrease, and $\mathrm{Kc}$ is the cryoscopic constant of water $\left(1.86^{\circ} \mathrm{C} / \mathrm{mol} / \mathrm{kg}\right)$. One osmole is equal to $1 \mathrm{~mole}$ for osmotic effects, which is the osmolality of the solution at the freezing point.

\subsubsection{Microbiological Analysis}

Microbiological analysis of TT beverages was based on Brazilian criteria (Resolution RDC 12) that establish presumptive tests for total and thermo-tolerant coliform Most Probable Number (MPN) and the absence of Salmonella sp. in a 25-mL sample (Brasil, 2001). For the MPN of total and thermo-tolerant coliforms and the determination of presence or absence of Salmonella sp., the APHA (American Public Health Association, 1992) recommendations were followed. Suspected Salmonella colonies were submitted to standard biochemical and serological tests (agglutination test performed with polyvalent flagellar antiserum) (Probac, São Paulo, Brazil).

\subsubsection{Sensory Evaluation}

Sensory evaluation was approved by the Human Research Ethics Committee (CEPSH) at UFSC, human ethics approval number 1076963. Sensory evaluation of the TT beverage was performed after 15 days of storage at $4{ }^{\circ} \mathrm{C}$. Sensory characteristics of the TT beverage were compared with those of the leading commercial pasteurized orange and carrot juices. Sensory hedonic testing of the beverages was performed according to Ferrari Pereira Lima, De Dea Lindner, Thomaz Soccol, Parada and Soccol (2012) by a group of 57 non-trained testers (elderly participants greater than 60 years old) from the Sector of Studies of Elderly (NETI) from UFSC. The participants were regular fruit juice consumers who judged the color, odor, taste and overall acceptability using a hedonic rating scale from 1 to 9 (1: extremely dislike; 2 : dislike very much; 3 : moderately dislike; 4 : slightly dislike; 5: neither like nor dislike; 6: slightly like; 7: moderately like; 8: like very much; 9: extremely like) (Meilgaard, Civille, \& Carr, 2007). Sensory tests were performed in individual booths under white light in the morning (9:00-11:30 a.m.). Samples were served refrigerated at $5{ }^{\circ} \mathrm{C}$ in transparent glass cups. The data obtained were analyzed by ANOVA and Tukey's test according to Monteiro (1994) using Assistat version 7.5 software (Assistat, Brazil). To verify the acceptability of the tested beverages, an acceptability factor ( $A F)$ (Dutcosky, 1996) using standardized criteria was calculated to evaluate each sensory analyzed attribute: $A F=A \bullet$ $100 / B$, where $A$ is the mean value obtained for each attribute, and $B$ is the maximum mean value ascribed to each attribute.

\subsection{Comparison of Preservation Process Technologies and Stabilization of the Beverage Components}

\subsubsection{Vitamin A}

An LC10AT high-performance liquid chromatography (HPLC) system (Shimadzu, Kyoto, Japan) equipped with a diode array detector (DAD) was used to measure vitamin $\mathrm{A}$ in the samples tested. Chromatographic separations were performed using an Eclipse XDB- $\mathrm{C}_{18}$ column - $150 \mathrm{~mm}$ x $4.6 \mathrm{~mm}, 5 \mu \mathrm{m}$ (Agilent Technologies, Palo Alto, CA, USA). The mobile phase was composed of $10 \%$ acetonitrile and $90 \%$ methanol/water $98 / 2$, and the device was operated in the isocratic mode with a flow rate of $1 \mathrm{~mL} / \mathrm{min}$. A total of $20 \mu \mathrm{L}$ of sample was injected, and the analyte was monitored at $330 \mathrm{~nm}$. The analyte was confirmed by enrichment of sample using a pharmaceutical standard of retinol and its UV-spectra. The retention time of the analyte was 4.4 min under the experimental conditions. For this assay, the peak area of vitamin A observed for the F matrix was considered 100 $\%$ concentration; the percentage of the analyte presented in the treated beverages could thus be estimated.

Before injection into the HPLC system, all samples were prepared as follows: $0.5 \mathrm{~mL}$ of chloroform was added to $2 \mathrm{~mL}$ of sample in a Falcon tube, and the mixture was vortexed for $1 \mathrm{~min}$ and centrifuged for $10 \mathrm{~min}$. Thereafter, $200 \mu \mathrm{L}$ of the organic phase was transferred to a microtube and dried using an $\mathrm{N}_{2}$ flow. The sample was resuspended using $100 \mu \mathrm{L}$ of acetonitrile and injected into the chromatographic system. 


\subsubsection{Vitamin C}

A 7100 capillary electrophoresis (CE) system (Agilent Technologies, Palo Alto, CA, USA) equipped with a DAD was used in this assay. For all analyses, a fused silica capillary with $32 \mathrm{~cm}$ total length $(23 \mathrm{~cm}$ of effective length) x $75 \mu \mathrm{m}$ internal diameter x $375 \mu \mathrm{m}$ outer diameter was used. Samples were injected hydrodynamically by applying 50 mbar for $3 \mathrm{~s}$, and the analyte was monitored at $266 \mathrm{~nm}$. The separation voltage was $25 \mathrm{kV}$ under positive polarity at the injection side, and the temperature was maintained at $25{ }^{\circ} \mathrm{C}$. To minimize instrumental errors, sorbic acid was used as internal standard. The background electrolyte (BGE) was composed of $40 \mathrm{mM}$ tris(hydroxymethyl)aminomethane (TRIS) and $20 \mathrm{mM}$ 2-(N-morpholino)ethanesulfonic acid (MES), buffered at $\mathrm{pH} 8.2$.

To quantify the concentration of vitamin $\mathrm{C}$ in the samples, a calibration curve was constructed using an analytical standard of ascorbic acid from 10.1-40.6 mg/L using 7 concentration levels. The limit of detection and quantification of the method were $0.4 \mathrm{mg} / \mathrm{L}$ and $1.35 \mathrm{mg} / \mathrm{L}$, respectively, calculated by the signal-to-noise ratio of 3:1 and 10:1, respectively.

Before injection into the $\mathrm{CE}$ system, $1 \mathrm{~mL}$ of sample was centrifuged, and the supernatant was collected and properly diluted to $1 \mathrm{~mL}$ of deionized water. Both the calibration curve and samples were prepared in duplicate, with a final internal standard concentration of $25 \mathrm{mg} / \mathrm{L}$.

\subsubsection{Enzymatic Activity}

Peroxidase (POD, EC 1.11.1.7) activity was determined according to the method described by Abreu and Faria (2007) and Campos, Souza, Coelho and Glória (1996), with modifications. A total of $7 \mathrm{~mL}$ of $0.2 \mathrm{M}$ buffer solution of monobasic sodium phosphate $(\mathrm{pH} 5.8), 1.5 \mathrm{~mL} 0.05 \%$ guaiacol (phenolic substrate) and $0.5 \mathrm{~mL} 0.1 \%$ hydrogen peroxide were added to a test tube maintained in a water bath at $35{ }^{\circ} \mathrm{C}$. After stabilization of the temperature, $1 \mathrm{~mL}$ of the treated beverage samples was added to the tube. The mixture was homogenized, and changes in absorbance at $470 \mathrm{~nm}$ were measured in a U-1800 UV/VIS Spectrophotometer (Hitachi, Berkshire, United Kingdom).

Polyphenol oxidase (PPO, EC 1.10.3.1) activity was determined according to the method described by Abreu and Faria (2007) and Campos et al. (1996), with modifications. Volumes of $5.5 \mathrm{~mL}$ of $0.2 \mathrm{M}$ buffer solution of monobasic sodium phosphate $(\mathrm{pH} 6.0)$ and $1.5 \mathrm{~mL}$ of $0.2 \mathrm{M}$ pyrocatechol solution (phenolic substrate) were added to a test tube maintained in a water bath at $25{ }^{\circ} \mathrm{C}$. After stabilization of the temperature, $1 \mathrm{~mL}$ of the treated beverage samples was added to the tube. The mixture was homogenized, and changes in absorbance at $425 \mathrm{~nm}$ were measured in a U-1800 UV/VIS Spectrophotometer.

The absorbance values were acquired after 10 min for both POD and PPO enzymes. The blank for analysis of both enzymes was a mixture of all the reactants, but replacing the beverage sample with distilled water. The enzyme activity was expressed in units $/ \mathrm{mL}$. One unit is equivalent to a change in absorbance of $0.001 / \mathrm{min} / \mathrm{mL}$ of sample. The following equation was used: Enzymatic activity $=\left(\mathrm{A} 10_{\text {sample }}-\mathrm{A} 0_{\text {sample }}\right)-\left(\mathrm{A} 10_{\text {blank }}-\mathrm{A} 0_{\text {blank }}\right) / 0.01$, where $\mathrm{A} 10$ is the absorbance after $10 \mathrm{~min}$ of the reaction, and $\mathrm{A} 0$ is the initial absorbance.

\subsubsection{Microbiological Challenge Testing}

To evaluate the effectiveness of the preservation processes used to deliver some degree of lethality against target potential pathogenic and/or spoilage microorganisms, a surrogate E. coli, ATCC 25922, and A. acidoterrestris ATCC 49025 were separately inoculated into the F matrix before treatment.

The E. coli stock culture was maintained on Brain-Heart Infusion agar (BHI) (Acumedia, Lansing, Michigan, USA) slants at $4{ }^{\circ} \mathrm{C}$. The cultures for the experiments were subcultured twice from the stock culture in nutrient broth (NB) (Oxoid, Basingstoke, Hampshire, England) incubated at $35^{\circ} \mathrm{C}$ for $18 \mathrm{~h}$. The culture was inoculated at a concentration of $1.5 \times 10^{6} \mathrm{CFU} / \mathrm{mL}$ in the $\mathrm{F}$ matrix. To evaluate the effect of the treatments on microbial inactivation, the enumeration of viable $E$. coli cells, after serial dilutions of the treated beverages in buffered peptone water, was obtained using violet red bile agar with 4-methylumbelliferyl- $\beta$-D-glucuronide (VRBA MUG) (Acumedia, Lansing, Michigan, USA) at $45{ }^{\circ} \mathrm{C} / 24 \mathrm{~h}$. Replicate counts in CFU were converted to log values and expressed as averaged log numbers.

A. acidoterrestris was cultivated in yeast glucose starch (YGS) medium $\mathrm{pH} 3.7$ at $45^{\circ} \mathrm{C}$ for 5 days according the methodology described by Alberice, Funes-Huacca, Barreto Guterres and Carrilho (2012). The spores obtained from the culture were spread onto YGS agar and incubated at $45{ }^{\circ} \mathrm{C}$ for 5 days. After reaching more than $90 \%$ of sporulation, as confirmed by microscopy following staining with malachite green, spores were collected with a sterile swab and resuspended in sterile distilled water. The spores collected were centrifuged at $4.500 \mathrm{~g}$ for 15 min at $4{ }^{\circ} \mathrm{C}$, washed two times with sterile distilled water, resuspended in acid sterile distilled water (pH 3.7) and 
stored at $-20{ }^{\circ} \mathrm{C}$ until use. The bacterial spore suspensions were activated by heat-shock at $80{ }^{\circ} \mathrm{C}$ for 10 min immediately prior to inoculation at a concentration of approximately $4 \times 10^{4} \mathrm{CFU} / \mathrm{mL}$ in the $\mathrm{F}$ matrix. The number of viable A. acidoterrestris cells was evaluated from serial dilutions of the treated beverages in YGS agar pH 3.7 ( $45{ }^{\circ} \mathrm{C} / 5$ days). Counts in $\mathrm{CFU}$ were obtained in the same manner as described above for E. coli.

Plate count agar (PCA) (Himedia, Mumbai, India) at $30^{\circ} \mathrm{C}$ for $48 \mathrm{~h}$ and dichloran rose bengal chlortetracycline (DRBC) (Acumedia, Lansing, Michigan, USA) at $25{ }^{\circ} \mathrm{C}$ for 5 days were used to enumerate the presence of uninoculated (naturally present in the $\mathrm{F}$ matrix) viable mesophilic aerobic bacteria and yeasts and molds, respectively, in the untreated and treated samples for each preservation process. Counts for CFU were performed in duplicate, and the mean values were calculated.

\section{Results and Discussion}

\subsection{Characterization of the Beverage}

\subsubsection{Physicochemical and Composition Characterization}

The characterization of the TT beverage, presented in Table 1, is consistent with those reported for coconut water and orange juices. The obtained $\mathrm{pH}$ values classified the beverage as low-acid, and the high carbohydrate content could contribute to the development of food-borne pathogen contamination (Walter, Kabuki, Esper, Sant'Anan, \& Kuaye, 2009). A beverage $\mathrm{pH}$ below 3.8 is significant for determining microbiological stability (Battey \& Schaffner, 2001) and is directly correlated with the product's taste. However, the thermo-acidophilic spore-forming bacteria Alicyclobacillus sp. (TAB) can not only survive the normal pasteurization procedure applied to fruit juices and beverages but also germinate and proliferate in acidic products (Smit, Cameron, Venter, \& Witthuhn, 2011).

Table 1. Characteristics of the TT beverage

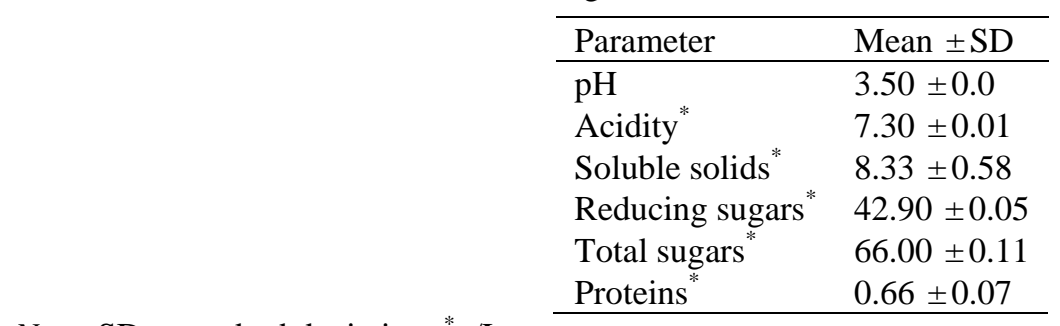

Note. $\mathrm{SD}=$ standard deviation; ${ }^{*} \mathrm{~g} / \mathrm{L}$.

The sugars that are known to contribute to the sweet taste in coconut water and orange juice are fructose, glucose and sucrose (Bilek \& Bayram, 2015; Camargo Prado et al., 2015). Trace amounts of protein were found in the beverage. The presence of free amino acids and reducing sugars may result in the occurrence of Maillard reactions during thermal processing, which would leads to nutritional and sensory changes in the beverage (Cappelletti et al., 2015).

\subsubsection{Vitamin C, Antioxidant Activity and Total Phenolic Content}

The concentrations of vitamin $\mathrm{C}$ as ascorbic acid in the $\mathrm{F}$ and TT beverage are shown in Table 2. Of this total, $180 \mathrm{mg} / \mathrm{L}$ was added to the beverage during formulation as a technological antioxidant and vitamin enrichment component. With this amount, the TT beverage achieves $162 \%$ of the RDI recommended in Brazil. Both vitamin $\mathrm{C}$ concentration and total phenolic content are strongly correlated with antioxidant capacity, as determined by the reduction of DPPH (Gardner, White, McPhail, \& Duthie, 2000). The DPPH assay has been widely used to test the ability of compounds to act as free radical scavengers or hydrogen donors. Santos et al. (2013) detected and quantified ascorbic acid in several varieties of coconut water $(25.8 \mathrm{mg} / \mathrm{L})$. In cell culture, the green dwarf variety of coconut water was efficient in protecting against oxidative damage induced by hydrogen peroxide. Vitamin $\mathrm{C}$ is highly bioavailable and is consequently one of the most important water-soluble antioxidants in cells (Halliwell, 1996). 
Table 2. Ascorbic acid content, antioxidant activity, total phenol content, omega 3 fatty acid content and osmolality of F (fresh untreated matrix) and TT (thermally treated beverage)

\begin{tabular}{lll}
\hline & F & TT \\
\hline Ascorbic acid (mg/L) & $291.73 \pm 0.68^{\mathrm{a}}$ & $285.23 \pm 1.45^{\mathrm{b}}$ \\
Antioxidant activity $\left(\%\right.$ inhibition of DPPH) $^{*}$ & $63.48 \pm 2.41^{\mathrm{a}}$ & $68.48 \pm 2.00^{\mathrm{b}}$ \\
Total phenol content (mg/L) $^{*}$ & $952.75 \pm 5.69^{\mathrm{a}}$ & $962.50 \pm 2.06^{\mathrm{b}}$ \\
Omega 3 fatty acids (mg/L) $_{\text {Osmolality (mOsmol/L) }}$ & 516.40 & 530.10 \\
Os & ND & 545.00 \\
\hline
\end{tabular}

Note. ${ }^{*}$ Mean \pm standard deviation. Values with different capital letters in the same line are significantly different $(P<0.05)$. ND= not determined.

The F matrix and TT beverage exhibited high ascorbic acid content due to the high ascorbic acid content in the orange juice $(403.15 \mathrm{mg} / \mathrm{L})$ and coconut water $(23.10 \mathrm{mg} / \mathrm{L})$, which were added to $40 \%$ and $48 \%$, respectively, in the beverage formulation. The consumption of fruit juice-based beverages contributes to overall antioxidant intake, with potentially beneficial biological effects for human health. Coconut water and orange juice were shown to have antioxidant activity, which was positively correlated with the concentration of flavanones and kinetin in orange juice and coconut water, respectively (Sánchez-Moreno et al., 2005; Yong et al., 2009). The F and TT beverage showed different results for antioxidant activity (Table 2). Comparison of the beverage with that in the study conducted by Ferrari Pereira Lima et al. (2012) showed that the anti-radical performance towards DPPH radicals was just below that of a fermented herbal mate beverage rich in phenolic compounds. According to Qin, Jin and Park (2010), individual phenolic compounds with high antioxidant activity might be produced during the fermentation process. Compared with other antioxidant beverages (Ramadan-Hassanien, 2008), especially those rich in caffeine, the TT beverage has high antioxidant capacity, slightly less than that of tea with lemon, green tea, black tea and soluble coffee.

The total phenolic content in the TT beverage was slightly above that of F (Table 2). The major contribution to phenolics in the beverage came from the orange juice. In a study conducted by Gardner and White (2000), the level of phenolic compounds in orange juice was $755 \mathrm{mg}$ GAE/L. As mentioned above, the addition of $40 \%$ of orange juice, increased the total phenolic content of the beverage. The use of orange juice in the formulation is thus important as a source of phenolic compounds. The coconut water, present in the formulation in the range of $46 \%$, did not contribute significantly to the total phenolic content; Santos et al. (2013) and Tan et al. (20140 found a low content of phenolics in coconut water $(99.40$ and $54.00 \mathrm{mg} / \mathrm{L}$, respectively).

\subsubsection{Omega 3 Fatty Acids}

The concentration of omega-3s (EPA+DHA) in the F and TT beverage is shown in Table 2. In this amount, a dose of $250 \mathrm{~mL}$ of beverage achieves $51.3 \%$ of the FAO minimal recommendation per day. Decreases in DHA status are associated with cognitive decline in the elderly and those with Alzheimer's (Abubakari, Naderali, \& Naderali, 2014). Human studies suggest that an adequate dietary intake of omega-3s could decrease age-related cognitive decline, may protect against senile dementia and provide better cognitive performance (Denis, Potier, Vancassel, \& Lavialle, 2013; D'Ascoli et al., 2016). García-Alonso, Jorge-Vidal, Ros and Periago (2012) compared the effects of consumption of omega-3-enriched tomato juice on serum lipid profiles and levels of biomarkers related to antioxidant status and cardiovascular disease (CVD) risk in healthy women. Stronger positive amelioration of CVD risk factors was observed following the intake of enriched juice, suggesting a possible synergistic action between omega-3s and tomato antioxidants $(362 \mathrm{mg} / \mathrm{L})$. In comparison, the TT beverage had 2.65-fold more total phenolics in almost the same amount of omega-3s. Hawthorne, Abrams and Heird (2009) evaluated the effects of providing a supplement of micro-encapsulated algal DHA in orange juice. They demonstrated that DHA supplementation of juice at either $50 \mathrm{mg} /$ day or $100 \mathrm{mg} /$ day for 6 weeks was effective in increasing the plasma phospholipid DHA contents of children.

\subsubsection{Osmolality}

The osmolality of the beverage, expressed in $\mathrm{mOsmol} / \mathrm{L}$, depends on its osmotic pressure. Osmolality is a crucial determinant of the physiological acceptance of the beverage. The desired osmolality should be $<700 \mathrm{mOsm}$ (Klang, McLymont, \& Ng, 2013). An appropriate osmolar load is necessary for the beverage be tolerated by a eutrophic elderly consumer, ensuring the successful assimilation of the formulation components. The osmolar concentration found in the TT beverage (Table 2) was $545.00 \mathrm{mOsm} / \mathrm{L}$, classifying the product as a hypertonic 
beverage (> $330 \mathrm{mOsmol} / \mathrm{L}$ ). Fruit juices are considered typical hypertonic beverages, with osmolality values in the range of 600-700 mOsmol/L (Henriques \& Rosado, 1999).

\subsubsection{Microbiological Analysis and Sensory Evaluation}

Microbial evaluation of total, thermo-tolerant coliforms and Salmonella sp. was performed (data not shown) in accordance with Brazilian criteria to ensure safe consumption of the TT beverage, indicating that efficient heat treatment occurred after a satisfactory hygienic process. Then, a panel of 57 non-trained elderly volunteers, each greater than 60 years old and a regular fruit juice consumer, participated in the evaluation. The acceptance levels for the TT beverage and the leading commercial pasteurized orange/carrot juice are presented in Table 3 . No significant differences in global evaluation, taste, color or aroma were obtained.

Table 3. Acceptance (average values \pm SD) and acceptability factors (AFs) for TT (thermally treated beverage) and commercial pasteurized orange/carrot juice

\begin{tabular}{lll}
\hline Attributes (AF) & TT beverage & Commercial pasteurized juice \\
\hline Global evaluation & $6.89 \pm 1.50^{\mathrm{a}}(100)$ & $5.61 \pm 2.20^{\mathrm{a}}(81)$ \\
Taste & $6.81 \pm 1.70^{\mathrm{a}}(100)$ & $5.19 \pm 2.30^{\mathrm{a}}(76)$ \\
Color & $7.12 \pm 1.80^{\mathrm{a}}(100)$ & $5.47 \pm 2.10^{\mathrm{a}}(77)$ \\
Aroma & $6.70 \pm 1.70^{\mathrm{a}}(100)$ & $5.42 \pm 2.10^{\mathrm{a}}(81)$
\end{tabular}

Note. ${ }^{a}$ Means \pm standard deviation with the same letter in the same line are not significantly different $(P>0.05)$.

These findings were in accordance with Camargo Prado et al. (2015), who evaluated a fermented coconut-based beverage supplemented with sucrose and artificial coconut flavor. Figure 2 shows that the TT beverage received the best overall rating from the panel. For the overall evaluation, the average values for the sensory analysis and acceptability factors were kept within the acceptance range. According to Dutcosky (1996), AF $\geq 70 \%$ represented good acceptability for the attribute analyzed in a sensory analysis. Therefore, product acceptance was good and was comparable to that of similar commercial beverages available at the local market.

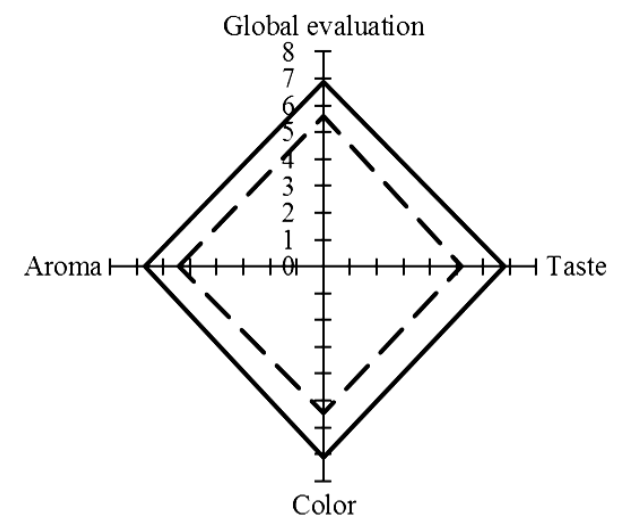

Figure 2. Characteristics of the acceptance profile of the TT beverage (thermally treated beverage) (solid line) and the leading commercial pasteurized orange/carrot juice (dashed line)

\subsection{Comparison of Preservation Process Technologies and Stabilization of the Beverage Components}

Thermal processes induce undesirable changes in beverages, such as micronutrient losses, through chemical reactions and leads to losses in perceived freshness (Rodríguez-Roque et al., 2015). Non-thermal beverage preservation technologies such as $\mathrm{SC}-\mathrm{CO}_{2}$ and $\mathrm{DMDC}$ have been developed as an alternative. Previous studies have reported that both technologies inactivate microorganisms without compromising the nutritional and sensory attributes of food (Yu, Xiao, Xu, Wu, \& Wen, 2014; Cappelletti et al., 2015).

\subsubsection{Vitamins A and C and Enzymatic Activity}

The analyses used to measure the reduction of vitamin content and enzymatic activity during the processes are described in table 4. 
Table 4. Vitamin A and ascorbic acid levels and peroxidase and polyphenol oxidase activities of coconut water (CW), fresh untreated matrix $(\mathrm{F})$, thermally treated beverage (TT), supercritical carbon dioxide-treated beverage $\left(\mathrm{SC}-\mathrm{CO}_{2}\right)$ and dimethyl dicarbonate-treated beverage (DMDC)

\begin{tabular}{lllllll}
\hline & & \multicolumn{5}{l}{ Preservation process } \\
\hline & Orange juice & Coconut water & $\mathrm{F}$ & $\mathrm{TT}$ & $\mathrm{SC}^{-\mathrm{CO}_{2}}$ & DMDC \\
\hline Vitamin A (\%) & n.d. & n.d. & 100 & 144 & 92 & 106 \\
Ascorbic acid $(\mathrm{mg} / \mathrm{L})^{*}$ & $403.15 \pm 0.78$ & $23.10 \pm 3.0$ & $291.73 \pm 3.68^{\mathrm{a}}$ & $285.23 \pm 1.45^{\mathrm{b}}$ & $245.69 \pm 0.52^{\mathrm{c}}$ & $279.30 \pm 8.86^{\mathrm{ab}}$ \\
Peroxidase $(\mathrm{U} / \mathrm{mL})$ & 7.40 & 66.30 & 3.90 & $\mathrm{ND}$ & $\mathrm{ND}$ & $\mathrm{ND}$ \\
Polyphenol oxidase $(\mathrm{U} / \mathrm{mL})$ & $\mathrm{ND}$ & 14.7 & $\mathrm{ND}$ & $\mathrm{ND}$ & $\mathrm{ND}$ & ND
\end{tabular}

Note. ${ }^{*}$ Means \pm standard deviation. n.d. $=$ not determined, $\mathrm{ND}=$ not detectable. ${ }^{\mathrm{a}, \mathrm{b}, \mathrm{c}}$ Values with different capital letters are significantly different $(P<0.05)$.

The TT beverage showed higher vitamin A values (increased 44\% in relation to F). This result was in agreement with a report by Sánchez-Moreno, Plaza, De Ancos and Cano (2003) that showed an increase in extractable carotenoids due to thermal treatment of orange juice. According to Schieber and Carle (2005), the availability of carotenoids may increase due to rupture of the food matrix by heat or mechanical treatment. Thermal processes increase the chemical extractability of carotenoids and other substances.

According to Zhou et al. (2009), who investigated the effect of $\mathrm{SC}-\mathrm{CO}_{2}$ on the quality of carrot juice, the $\mathrm{SC}-\mathrm{CO}_{2}$ treatment resulted in an $8 \%$ decrease in the vitamin A concentration, and they observed that carotenoids in the treated juices were stable. Carotenoids are bound to protein and membrane lipids. Processes that apply high pressure are known to affect food macromolecular structures. Sánchez-Moreno et al. (2005) found that in orange juice, high pressure processes increased the release of carotenoids from the suspended pulp particles, making them more accessible to extraction and leading to increased carotenoid release and vitamin A values. Our result, in accordance to Johannsen and Brunner (1997), may be related to the solubility of fat-soluble vitamins after supercritical $\mathrm{CO}_{2}$ interaction that is correlated with differences in the temperature and density of $\mathrm{CO}_{2}$ applied.

Compared to F, the DMDC treatment showed a 6\% increase in the vitamin A concentration. There is little known about the interaction between this molecule and vitamin A. More research could clarify the mechanism of interaction between DMDC treatment and vitamins.

The content of ascorbic acid from the treatments analyzed is reported in Table 4. Before the addition of ascorbic acid to the beverage formulation, ascorbic acid was measured as 23.10 and $403.15 \mathrm{mg} / \mathrm{L}$ for coconut water and orange juice, respectively. Significant differences among the preservation processes were detected. In contrast, Rodríguez-Roque et al. (2015) and Sánchez-Moreno et al. (2005) showed that the greatest losses of this bioactive compound were found in TT fruit juice beverages (by $31 \%$ and $9 \%$, respectively, compared with untreated matrixes) subjected to different preservation technologies. Vitamin $\mathrm{C}$ is a heat-sensitive nutrient and is vulnerable to enzyme-catalyzed oxidation by oxidoreductases (e.g., ascorbate oxidase and POD) (Davey et al., 2000). In our work, the treatments applied may have partially eliminated some of the enzymes responsible for vitamin $\mathrm{C}$ loss. Thermal treatments with higher temperature tended to result in a higher decrease in the content of vitamin $\mathrm{C}$, but in our case, the binomial time-temperature applied in the TT process demonstrated no significant difference from non-thermal treatments.

There was no significant degradation of ascorbic acid after treatment with DMDC (Table 4). Yu et al. (2014) treated fermented litchi juice with DMDC and observed, contrary to our results, a 58.1\% reduction in the ascorbic acid content relative to the fresh sample. Leong and Oey (2012) reported that ascorbic acid was minimally reactive with DMDC and that the loss of the compound could be attributed to ascorbic acid oxidases in the juice during DMDC treatment. In our case, depleting dissolved oxygen in the deaeration process and filling the bottle headspace with $\mathrm{N}_{2}$ both inhibited the oxidation of ascorbic acid.

SC- $\mathrm{CO}_{2}$ treatment using $20 \mathrm{MPa}$ showed the greatest decrease in ascorbic acid content, a more than $15 \%$ reduction compared with F (Table 4). According to Fabroni, Amenta, Timpanaro and Rapisarda (2010), the addition of $\mathrm{CO}_{2}$ to orange juice is probably beneficial for ascorbic acid retention due to the displacement of dissolved oxygen from the liquid matrix. Fabroni et al. (2010) applied $\mathrm{CO}_{2}$ over $23 \mathrm{MPa}$ for $15 \mathrm{~min}$, and 6\% ascorbic acid in the juice was degraded, but at lower pressures (13 MPa), the concentration remained unchanged. They concluded that lower operative pressures are likely to be beneficial for the retention of ascorbic acid, and 
the change in $\mathrm{CO}_{2}$ concentration did not appear to have an influence.

Higher concentrations of POD and PPO were found in coconut water (Table 4), the major component of the beverage. In orange juice and $\mathrm{F}$, the high concentration of ascorbic acid and the $\mathrm{pH}$ of 3.5 , respectively, were sufficient to inhibit enzyme activities. These results are in accordance with Abreu and Faria (2007), who reported that the addition of ascorbic acid was effective in the inactivation of PPO in coconut water before heat treatment. Campos et al. (1996) showed that $20 \mathrm{mg}$ of ascorbic acid per $100 \mathrm{~mL}$ of coconut water was sufficient to reduce the activity of both oxidoreductases. Cultivar differences and component matrix variations during fruit maturity are key elements in the variations in enzymatic value.

No enzyme activity was detected in the TT, SC- $\mathrm{CO}_{2}$ or DMDC beverages (Table 4), which could be related to the synergic effect of the treatments, the presence of ascorbic acid in the formulation and/or the low $\mathrm{pH}$ of the beverage. Campos et al. (1996) and Tan et al. (2014) reported that thermal treatment had a pronounced effect on the activities of POD and PPO in coconut water, with a drastic decrease observed at higher heating temperatures. The results showed that complete inactivation of POD was achieved with heat treatment at $90{ }^{\circ} \mathrm{C}$ and a holding time of $2.5 \mathrm{~min}$. The cited works also reported a similar result; PPO was more heat-resistant than POD.

Yu et al. (2014) used DMDC in litchi juice and observed that the content of ascorbic acid increased in Lactobacillus casei-fermented juice; this result was attributed to the deoxidization of oxidized ascorbic acid. During a four-week period, no large variations in color were observed, demonstrating the stability of the enzyme activities in the DMDC-treated juice. According to Wang et al. (2013), DMDC can inhibit the activity of PPO and POD, contributing to the maintenance of ascorbic acid content.

Depending on the processing parameters (e.g., temperature, pressure and depressurization rate), $\mathrm{SC}-\mathrm{CO}_{2}$ may negatively affect the enzyme activity due to conformational changes caused by gas in the secondary and tertiary structure. Gui et al. (2007) observed that cloudy apple juice, when exposed to $\mathrm{SC}_{-} \mathrm{CO}_{2}$ at $30 \mathrm{MPa}\left(55^{\circ} \mathrm{C}\right.$ for 60 min), presented a reduction in PPO activity of over 60\%, which was greater than that observed under atmospheric conditions at the same temperature (27.9\% reduction) and indicated a combined effect of pressure, temperature and time after SC- $\mathrm{CO}_{2}$ treatment. Four years later, $\mathrm{Xu}$ et al. (2011) studied the $\mathrm{SC}-\mathrm{CO}_{2}$-mediated inactivation of enzymes in the same matrix. PPO was completely inactivated after $10 \mathrm{~min}$ of treatment at $22 \mathrm{MPa}$ and $60{ }^{\circ} \mathrm{C}$. Liu, Hub, Zhaoc and Song (2012) studied the effect of $\mathrm{SC}^{-\mathrm{CO}_{2}}$ on watermelon juice and obtained 95.8\% reductions in PPO activity and 57.9\% in PDO when $30 \mathrm{MPa}$ pressure was applied at $50{ }^{\circ} \mathrm{C}$ for 50 min. The cited works reported that the major effect of $\mathrm{SC}-\mathrm{CO}_{2}$ on enzymes occurred during the first minutes of treatment, in accordance with our results.

\subsubsection{Microbiological Challenge Testing}

The inoculum level used in a microbiological challenge depends on the objective of the study. In our case, the level was determined for validation of process lethality, and $10^{6} \mathrm{CFU} / \mathrm{mL}$ for $E$. coli was used to demonstrate the extent of reduction in the challenge. In the USA, juice processors are required to demonstrate a 5 log reduction in relevant hazardous microorganisms in their products (5 D performance standard) (U.S. FDA, 2016).

Several pathogenic bacteria may resist the inherent acidity of fruit juice and develop adaptive mechanisms that enhance their survival and sometimes even their ability to grow in acidic environments. Analysis of the data (Table 5) showed that the TT and DMDC processes could deliver the required level of lethality according to the pre-determined performance standard of a $5 \mathrm{log}$ reduction for juices (U.S. FDA, 2016). The $\mathrm{SC}^{-\mathrm{CO}_{2}}$ treatment demonstrated a $3.38 \mathrm{log}$ reduction. Our results are in agreement with those of (Basaran-Akgul, Churey, Basaran, \& Worobo, 2009), who challenged apple cider ( $\mathrm{pH} 4.0$ ) by inoculating $10^{6}-10^{7} \mathrm{CFU}$ of three different strains of E. coli $\mathrm{O} 157: \mathrm{H} 7$ per $\mathrm{mL}$ of juice. A greater than $5 \log$ reduction was achieved at room temperature with $250 \mathrm{ppm}$ DMDC after incubation for $6 \mathrm{~h}$. Treatment with DMDC may offer a viable alternative to TT for the production of safe juice. 
Table 5. Viable cell counts ( $\log$ orders $\mathrm{CFU} / \mathrm{mL})$ performed in duplicate. The results are presented as the mean values for E. coli ATCC 25922, A. acidoterrestris ATCC 49025, mesophilic aerobic bacteria, yeasts and molds in the fresh untreated matrix (F), thermally treated beverage (TT), supercritical carbon dioxide-treated beverage (SC-CO2) and dimethyl dicarbonate-treated beverage (DMDC)

\begin{tabular}{llllll}
\hline & \multicolumn{5}{l}{ Preservation process } \\
\hline & Medium & $\mathrm{F}$ & $\mathrm{TT}$ & $\mathrm{SC}^{-C O} \mathrm{C}_{2}$ & $\mathrm{DMDC}$ \\
\hline E. coli ATCC 25922 & VRBA MUG & 6.08 & $\mathrm{ND}$ & 2.70 & $\mathrm{ND}$ \\
A. acidoterrestris ATCC 49025 & YGS & 4.60 & 2.60 & 2.78 & 2.18 \\
Mesophilic aerobic bacteria $^{*}$ & PCA & 2.60 & ND & 1.70 & 2.18 \\
Yeasts and molds $^{*}$ & DRBC & 3.48 & 2.70 & 3.30 & 2.30 \\
\hline
\end{tabular}

Note. $\mathrm{ND}=$ colonies not detected - counts below the detection limit $(1 \mathrm{CFU} / \mathrm{mL}) .{ }^{*}$ Enumeration of uninoculated microorganisms (naturally present in the matrix).

E. coli ATCC 25922 demonstrated some level of resistance to the conditions applied in the $\mathrm{SC}-\mathrm{CO}_{2}$ treatment (Table 5). Silva et al. (2013) used SC- $\mathrm{CO}_{2}$ to build an inactivation curve for the same ATCC 25922 strain. The researchers obtained considerable log reductions using pressures of $10 \mathrm{MPa} / 25 \mathrm{~min}$ and found that microbial inactivation increases with increasing supercritical $\mathrm{CO}_{2}$ pressure cycles and system pressure. The food matrix can cause variations in the ability of pressurized $\mathrm{CO}_{2}$ to physicochemically act (four mechanisms described by Spilimbergo and Bertucco, 2003) to lead to loss of cell viability and the resistance and recovery of the microorganism (Debs-Louka, Louka, Abraham, Chabot, \& Allaf, 1999).

Detectable taint production in fruit juice is generally reported when the levels of A. acidoterrestris reach approximately 4 to $5 \log \mathrm{CFU} / \mathrm{mL}$ (Molva \& Baysal, 2015); using this information, we chose to inoculate $4 \log$. TT reduced the concentration of $A$. acidoterrestris in the beverage by $2 \log$ (Table 5). The heat resistance of $A$. acidoterrestris was reported in several studies. According to Bevilacqua, Sinigaglia and Corbo (2008), it is necessary to correlate heat with $\mathrm{pH}$ and soluble solids concentration to achieve a significant reduction in thermoacidophilic bacteria (TAB) because the resistance of endospores is strain-dependent. Alberice et al. (2012) investigated heat treatment and incubation time in orange juice inoculated with $4 \log \mathrm{CFU} / \mathrm{mL}$ of $A$. acidoterrestris spores to evaluate the best temperature for inactivation. At $87{ }^{\circ} \mathrm{C}$, counts of cell viability decreased slowly within the first $50 \mathrm{~min}$ of incubation. The best inactivation was obtained with a one and two minutes at $99^{\circ} \mathrm{C}$.

Viable A. acidoterrestris cells demonstrated resistance to inactivation with DMDC treatment (Table 5). The reduction observed was only $2.18 \mathrm{log}$. According to Chen, Harte, Davison and Golden (2013), DMDC (250 ppm) reduced the initial vegetative cell population by $2 \log \mathrm{CFU} / \mathrm{mL}$ in Bacillus acidoterrestris thermophilic broth and significantly increased the time to reach stationary phase. During the hydrolysis period, DMDC demonstrated activity, achieving some level of reduction for vegetative cells and spores, but after hydrolysis occurred, considerable growth of cells was detected. Therefore, the hydrolysis time was not sufficient to affect spores structured to resist environmental stresses. Although DMDC treatment may help control the vegetative cells of $A$. acidoterrestris, it may not provide adequate overall control for spores. Based on these results, the use of other antimicrobial agents for long shelf-life products is recommended.

The SC-CO2 treatment also failed to achieve the expected effectiveness for A. acidoterrestris; the reduction observed was only $1.82 \log$ (Table 5). This technique combines many variables, such as pressure, pressurization/depressurization rate and cycles, temperature and process time, which are necessary to apply an experimental design to evaluate the behavior of conditions with the juice matrix. According to Garcia-Gonzalez et al. (2009), both Gram-positive and Gram-negative bacteria can be sensitized by $10 \mathrm{MPa} \mathrm{SC}-\mathrm{CO}_{2}$ at $35^{\circ} \mathrm{C}$ for 20 min, but yeasts and the vegetative cells of A. acidoterrestris in apple juice show higher resistance (reduction of 2.0 and $0.3 \log$, respectively).

In the present study, negative results were recorded for A. acidoterrestris in all treatments tested even though viable spores may be present in the beverage. Consequently, defective batches of juice may enter the filling line after treatment. Therefore, the fate of A. acidoterrestris spores in our beverage is worthy of investigation. No shelf life tests were conducted to further explore the prevalence of the strain with time after treatment.

Viable mesophilic aerobic bacteria, yeasts and molds were tested in terms of resistance to inactivation by the applied treatments (Table 5). Thermal treatment was able to reduce the total cultivable mesophilic aerobic bacteria naturally present in the matrix, in accordance with the results of Cappelletti et al. (2015). SC-CO $\mathrm{CO}_{2}$ and DMDC were 
not able to act similarly. Furthermore, our results demonstrate that the applied treatments were not adequate to reduce naturally present yeasts and molds. Many fungi have the ability to produce ascospores that survive heat treatment, germinating within the packaging and causing deterioration. Salomão, Muller, Couto do Amparo and Falcão de Aragão (2014) evaluated molds and yeasts in the apple juice heat concentration process and identified heat-resistant molds such as Byssochlamys fulva. Consistent with our results, Yu et al. (2014) achieved a small reduction of 3.5 and $1.6 \log$ for yeast and molds, respectively, in fermented litchi juice by applying DMDC (250 $\mathrm{mg} / \mathrm{L}$ ) at $30^{\circ} \mathrm{C}$. Generally, molds are more resistant to DMDC treatment than are yeasts and bacteria.

In conclusion, preventive interventions through dietary modification are attractive strategies for promoting the health of the elderly. RTD beverages are a great vehicle for healthful ingredients for elderly consumers' dietary needs, vulnerabilities, preferences and restrictions because of their convenience and availability. The developed beverage can contribute to vitamin $\mathrm{C}$, antioxidant, phenolic, omega-3 and fiber intake. The osmolality tests indicate that the beverage is hypertonic and appropriate for tolerance by eutrophic elderly consumers, ensuring the assimilation of the formulation components. The study demonstrated that TT was more effective than the $\mathrm{SC}-\mathrm{CO}_{2}$ and DMDC treatments in preserving bioactive compounds in the fresh beverage, but the alternative non-thermal preservation methods represented a promising alternative to thermal processing for microbiologically stabilizing beverages without altering their quality attributes. The beneficial effects of the beverage as a healthy product should be explored in further studies, including trials with the elderly. Such research will provide insights into the use of the beverage as a non-dairy substrate and its introduction as a new vehicle for the consumption of functional beverages, especially by vegans and/or vegetarians and lactose-intolerant elderly.

\section{Acknowledgments}

The authors thank CNPq for financial support and scholarships, Lanxess for the Velcorin (DMDC) and NETI (UFSC) for sensory evaluation support.

\section{References}

Abreu, L. F., \& Faria, J.A.F. (2007). Temperature and ascorbic acid effects in physico-chemical stability and enzimatic activity of coconut water (Cocos nucifera L.) aseptic filled. Food Science and Technology, 2, 226-232. https://doi.org/10.1590/S0101-20612007000200003

Abubakari, A. R., Naderali, M. M., \& Naderali, E. K. (2014). Omega-3 fatty acid supplementation and cognitive function: are smaller dosages more beneficial? International Journal of Genetical Medicine, 19, 463-473. https://doi.org/10.2147/IJGM.S67065

Agcam, E., Akyıldız, A., \& Akdemir Evrendilek, G. (2014). Comparison of phenolic compounds of orange juice processed by pulsed electric fields (PEF) and conventional thermal pasteurisation. Food Chemistry, 143, 354-361. https://doi.org/10.1016/j.foodchem.2013.07.115.

Alberice, J. V., Funes-Huacca, M. E., Barreto, Guterres, S., \& Carrilho, E. (2012). Inactivation of Alicyclobacillus acidoterrestris in orange juice by saponin extracts combined with heat-treatment. International Journal of Food Microbiology, 159, 130-135. https://doi.org/10.1016/j.ijfoodmicro.2012.08.004

AOAC. (2000). Association of Official Analytical Chemistry, Official methods of analysis. Washington, USA.

AOAC. (2005). Association of Official Analytical Chemistry, Official methods of analysis. Washington, USA.

APHA. (1992). Standard Methods for the Examination of Water and Wastewater. 18th edition, American Public Health Association (APHA), American Water Works Association (AWWA) and Water Pollution Control Federation (WPCF). Washington, USA.

Basaran-Akgul, N., Churey, J. J., Basaran, P., \& Worobo, R. W. (2009). Inactivation of different strains of Escherichia coli $\mathrm{O} 157: \mathrm{H} 7$ in various apple ciders treated with dimethyl dicarbonate (DMDC) and sulfur dioxide (SO2) as an alternative method. Food Microbiology, 26, 8-15. https://doi.org/10.1016/j.fm.2008.07.011

Battey, A. S., \& Schaffner, D. W. (2001). Modelling bacterial spoilage in cold filled ready to drink beverages by Acinetobacter calcoaceticus and Gluconobacter oxydans. Journal of Applied Microbiology, 91, 237-247. https://doi.org/10.1046/j.1365-2672.2001.01381.x

Besser, R. E., Lett, S. M., Weber, J. T., Doyle, M. P., Barret, T. J., Wells, J. G., \& Griffin, P. M. (1993). An outbreak of diarrhea and hemolytic uremic syndrome from Escherichia coli O157:H7 in fresh pressed apple cider. JAMA, 269, 2217-2220. https://www.ncbi.nlm.nih.gov/pubmed/8474200 
Bevilacqua, A., Sinigaglia, M., \& Corbo, M.R. (2008). Alicyclobacillus acidoterrestris: new methods for inhibiting spore germination. International Journal of Food Microbiology, 125, 103-110. https://doi.org/10.1016/j.ijfoodmicro.2008.02.030

Bilek, S. E., \& Bayram, S. K. (2015). Fruit juice drink production containing hydrolyzed collagen. Journal of Functional Foods, 14, 562-569. https://doi.org/10.1016/j.jff.2015.02.024

Brasil. (2001). ANVISA - Agência Nacional de Vigilância Sanitária. Resolução RDC 12. Regulamento técnico sobre padrões microbiológicos para alimentos.

Brasil. (2005). ANVISA - Agência Nacional de Vigilância Sanitária. Resolução RDC 269. Regulamento técnico sobre a ingestão diária recomendada (IDR) de proteína, vitaminas e minerais.

Brasil. (2008). ANVISA - Agência Nacional de Vigilância Sanitária. Alimentos com Alegações de Propriedades Funcionais e ou de Saúde, Novos Alimentos/Ingredientes, Substâncias Bioativas e Probióticos. IX - Lista de alegações de propriedade funcional aprovadas.

Camargo Prado, F., De Dea Lindner, J., Inaba, J., Thomaz-Soccol, V., Kaur Brar, S., \& Soccol, C. R. (2015). Development and evaluation of a fermented coconut water beverage with potential health benefits. Journal of Functional Food, 12, 489-497. https://doi.org/10.1016/j.jff.2014.12.020

Campos, C. F., Souza, P. E. A., Coelho, V., \& Glória, M. B. A. (1996). Chemical composition, enzyme activity and effect of enzyme inactivation on flavour quality of green coconut water. Journal of Food Processes and Preservation, 20, 487-500. https://doi.org/10.1111/j.1745-4549.1996.tb00761.x

Cappelletti, M., Ferrentino, G., Endrizzi, I., Aprea, E., Betta, E., Corollaro, M. L., Charles, M., Gasperi, F., Spilimbergo, S. (2015). High Pressure Carbon Dioxide pasteurization of coconut water: A sport drink with high nutritional and sensory quality. Journal of Food Engineering, 145, 73-81. https://doi.org/10.1016/j.jfoodeng.2014.08.012

Chen, W., Harte, F. M., Davidson, P. M., \& Golden, D. A. (2013). Inactivation of Alicyclobacillus acidoterrestris using high pressure homogenization and dimethyl dicarbonate. Journal of Food Protection, 76, 1041-1045. https://doi.org/10.4315/0362-028X.JFP-12-443

Corona, O., Randazzo, W., Miceli, A., Guarcello, R., Francesca, N., Erten, H., Moschetti, G., \& Settanni, L. (2016). Characterization of kefir-like beverages produced from vegetable juices. LWT - Food Science and Technology, 66, 572-581. https://doi.org/10.1016/j.lwt.2015.11.014

Damar, S., \& Balaban, M. O. (2006). Review of dense phase CO2 technology: microbial and enzyme inactivation, and effects of food quality. Journal of Food Science, 71, 1-11. https://doi.org/10.1111/j.1365-2621.2006.tb12397.x

D'Ascoli, T. A, Mursu, J., Voutilainen, S., Kauhanen, J., Tuomainen, T. P., \& Virtanen, J. K. (2016). Association between serum long-chain omega-3 polyunsaturated fatty acids and cognitive performance in elderly men and women: The Kuopio Ischaemic Heart Disease Risk Factor Study. European Journal of Clinical Nutrition, 70, 970-975. https://doi.org/10.1038/ejen.2016.59

Davey, M. W., Van Monagu, M., Inze, D., Sanmartin, M., Kanellis, A., Smirnoff, N., ... Fletcher, J. (2000). Plant L-ascorbic acid: chemistry, function, metabolism, bioavailability and effects of processing. Journal of Science Food and Agriculture, 80, 825-860. https://doi.org/10.1002/(SICI)1097-0010(20000515)80:7<825::AID-JSFA598>3.0.CO;2-6

Debs-Louka, E., Louka, N., Abraham, G., Chabot, V., \& Allaf, K. (1999). Effect of Compressed Carbon Dioxide on Microbial Cell Viability. Applied Environmental Microbiology, 65, 626-631. http://aem.asm.org/content/65/2/626.short

Denis, I., Potier, B., Vancassel, S., \& Lavialle, H.C. (2013). Omega-3 fatty acids and brain resistance to ageing and stress: Body of evidence and possible mechanisms. Ageing Research Review, 12, 579-594. https://doi.org/10.1016/j.arr.2013.01.007

Dutcosky, S. D. (1996). Análise sensorial de alimentos. Champagnat, Curitiba, Brasil, pp.123.

Fabroni, S., Amenta, M., Timpanaro, N., \& Rapisarda, P. (2010). Supercritical carbon dioxide-treated blood orange juice as a new product in the fresh fruit juice market. Innovative Food Science \& Emerging Technology, 11, 477-484. https://doi.org/10.1016/j.ifset.2010.02.004

Ferrari Pereira Lima, I., De Dea Lindner, J., Thomaz Soccol, V., Parada, J. L., \& Soccol, C. R. (2012). Development of an Innovative Nutraceutical Fermented Beverage from Herbal Mate (Ilex paraguariensis 
A.St.-Hil.) Extract. International Journal of Molecular Science, 13, 788-800. https://doi.org/10.3390/ijms13010788

García-Alonso, F. J., Jorge-Vidal, V., Ros, G., \& Periago, M. J. (2012). Effect of consumption of tomato juice enriched with n-3 polyunsaturated fatty acids on the lipid profile, antioxidant biomarker status, and cardiovascular disease risk in healthy women. European Journal of Nutrition, 51, 415-424. https://doi.org/10.1007/s00394-011-0225-0

Garcia-Gonzalez, L., Geeraerd, A. H., Elst, K., Van Ginneken, L., Van Impe, J. F., \& Devlieghere, F. (2009). Influence of type of microorganism, food ingredients and food properties on high-pressure carbon dioxide inactivation of microorganisms. International Journal of Food Microbiology, 28, 253-263. https://doi.org/10.1016/j.ijfoodmicro.2008.12.005

Gardner, P. T., White, T. A. C., McPhail, D. B., \& Duthie, G. G. (2000). The relative contributions of vitamin C, carotenoids and phenolics to the antioxidant potential of fruit juices. Food Chemistry, 68, 471-474. https://doi.org/10.1016/S0308-8146(99)00225-3

Gui, F., Wu, J., Chen, F., Liao, X., Hu, X., Zhang, Z., \& Wang, Z. (2007). Inactivation of polyphenol oxidases in cloudy apple juice exposed to supercritical carbon dioxide. Food Chemistry, 100, 1678-1685. https://doi.org/10.1016/j.foodchem.2005.12.048

Halliwell, B. (1996). Vitamin C: antioxidant or pro-oxidant in vivo? Free Radical Research, 25, 439-454. https://doi.org/10.3109/10715769609149066

Hartman, L., \& Lago, R. C. A. (1973). Rapid preparation of fatty acid methyl esters from lipids. Laboratorial Practice, 175-176. https://www.researchgate.net/publication/18441624_Rapid_preparation_of_fatty_acids_methyl_esters

Hawthorne, K. M., Abrams, S. A., \& Heird, W. C. (2009). Docosahexaenoic Acid (DHA) Supplementation of Orange Juice Increases Plasma Phospholipid DHA Content of Children. Journal of American Dietology Association, 109, 708-712. https://doi.org/10.1016/j.jada.2008.12.024

Henriques, G. S., \& Rosado, G. P. (1999). Formulação de dietas enterais artesanais e determinação da osmolalidade pelo método de crioscópio. Revista Nutrição, 13, 225-232. https://doi.org/10.1590/S1415-52731999000300003

Johannsen, M., \& Brunner, G. (1997). Solubilities of the fat-soluble vitamins A, D, E, and K in supercritical carbon dioxide. Journal of Chemistry \& Engineering Data, 42, 106-111. https://doi.org/10.1021/je960219m

Klang, M., McLymont, V., \& Ng, N. (2013). Osmolality, pH, and Compatibility of Selected Oral Liquid Medications With an Enteral Nutrition Product. Journal of Parenteral and Enteral Nutrition, 37, 689-694. https://doi.org/10.1177/0148607112471560

Leong, S. Y., \& Oey, I. (2012). Effect of endogenous ascorbic acid oxidase activity and stability on vitamin C in carrots (Daucus carota subsp. sativus) during thermal treatment. Food Chemistry, 134, 2075-2085. https://doi.org/10.1016/j.foodchem.2012.04.002

Leyer, G. J., Wang, L. H., \& Johnson, E. A. (1995). Acid adaptation of Escherichia coli O157:H7 increases survival in acidic foods. Applied Environmental Microbioliology, 61, 3752-3755. https://www.ncbi.nlm.nih.gov/pubmed/7487011

Liu, Y., Hub, X., Zhaoc, X., \& Song, H. (2012). Combined effect of high pressure carbon dioxide and mild heat treatment on overall quality parameters of watermelon juice. Innovative Food Science \& Emerging Technology, 13, 112-119. https://doi.org/10.1016/j.ifset.2011.11.001

Lowry, O. H., Rosebrough, N. J., Farr, A. L., \& Randall, R. J. (1951). Protein measurement with the Folin phenol reagent. Journal of Biological Chemistry, 193, 265-275. http://devbio.wustl.edu/InfoSource/ISPDFs/Lowry\%201951.pdf

Meilgaard, M., Civille, G. V., \& Carr, B. T. (2007). Sensory Evaluation Techniques. CRC Press, Boca Raton, USA.

Miller, G. L. (1959). Use of dinitrosalicylic acid reagent for determination of reducing sugars. Analitical Chemistry, 31, 426-428.

http://download.bioon.com.cn/upload/month_1002/20100202_79e2638a4a8db64734c5QyCZjgBzadbY.atta ch.pdf

Molva, C., \& Baysal, A. H. (2015). Effects of pomegranate and pomegranate-apple blend juices on the growth 
characteristics of Alicyclobacillus acidoterrestris DSM 3922 type strain vegetative cells and spores. International Journal of Food Microbiology, 200, 52-56. https://doi.org/10.1016/j.ijfoodmicro.2015.01.019

Monteiro, C. L. B. (1994). Técnicas de Avaliação Sensorial. UFPR/CEPPA, Curitiba, Brazil, pp. 101.

Oteiza, J. M., Soto, S., Alvarenga, V. O., Sant'Ana, A. S., \& Gianuzzi, L. (2015). Fate of Alicyclobacillus spp. in enrichment broth and in juice concentrates. International Journal of Food Microbiology, 210, 73-78. https://doi.org/10.1016/j.ijfoodmicro.2015.05.021

Qin, Y., Jin, X., \& Park; D. H. (2010). Comparison of antioxidant activities in black soybean preparations fermented with various microorganisms. Agriculture Science China, 9, 1065-1071. https://doi.org/10.1016/S1671-2927(09)60191-7

Ramadan, M. F., Kroh, L. W., \& Moersel, J. T. (2003). Radical scavenging activity of black cumin (Nigella sativa L.), coriander (Coriandrum sativum L.) and niger (Guizotia abyssinica Cass.) crude seed oils and oil fractions. Journal of Agriculture and Food Chemistry, 51, 6961-6969. https://doi.org/10.1021/jf0346713

Ramadan-Hassanien M. F. (2008). Total antioxidant potential of juices, beverages and hot drinks consumed in Egypt screened by DPPH in vitro assay. Grasas y Aceites, 59, 254-259. https://doi.org/http://dx.doi.org/10.3989/gya.2008.v59.i3.516

Rawson, A., Patras, A., Tiwari, B. K., Noci, F., Koutchma, T., \& Brunton, N. (2011). Effect of thermal and non-thermal processing technologies on the bioactive content of exotic fruits and their products: review of recent advances. Food Research International, 44, 1875-87. https://doi.org/10.1016/j.foodres.2011.02.053

Rodríguez-Roque, M. J., de Ancos, B., Sánchez-Moreno, C., Pilar Cano, M., Elez-Martínez, P., \& Martín-Belloso, O. (2015). Impact of food matrix and processing on the in vitro bioaccessibility of vitamin C, phenolic compounds, and hydrophilic antioxidant activity from fruit juice-based beverages. Journal of Functional Foods, 14, 33-43. https://doi.org/10.1016/j.jff.2015.01.020

Salomão, B. C. M., Muller, C., Couto do Amparo, H., \& Falcão de Aragão, G. M. (2014). Survey of molds, yeast and Alicyclobacillus spp. from a concentrated apple juice productive process. Brazilian Journal of Microbiology, 45, 49-58. https://doi.org/10.1590/S1517-83822014000100008

Sánchez-Moreno, C., Plaza, L., De Ancos, B., \& Cano, M. P. (2003). Effect of high-pressure processing on health-promoting attributes of freshly squeezed orange juice (Citrus sinensis L.) during chilled storage. European Food Research and Technology, 216, 18-22. https://doi.org/10.1007/s00217-002-0625-8

Sánchez-Moreno, C., Plaza, L., Elez-Martínez, P., De Ancos, B., Martín-Belloso, O., \& Cano, M. P. (2005). Impact of high pressure and pulsed electric fields on bioactive compounds and antioxidant activity of orange juice in comparison with traditional thermal processing. Journal of Agriculture and Food Chemistry, 53, 4403-4409. https://doi.org/10.1021/jf048839b

Santos, J., Bispo, V.S., Filho, A.B.C., Pinto, I.F.D., Dantas, L.S., Vasconcelos, D.F., .. Matos, H.R. (2013). Evaluation of Chemical Constituents and Antioxidant Activity of Coconut Water (Cocus nucifera L.) and Caffeic Acid in Cell Culture. Annals da Academia Brasileira de Ciências, 85, 1235-1246. https://doi.org/10.1590/0001-37652012105312

Schieber, A., \& Carle, R. (2005). Occurrence of carotenoid cis-isomers in food: technological, analytical, and nutritional implications. Trends in Food Science \& Technology, 16, 416-422. https://doi.org/10.1016/j.tifs.2005.03.018

Silva, J. M., Rigo, A. A, Dalmolin, I. A., Debien, I., Cansian, R. L., Oliveira, J. V., \& Mazutti, M. A. (2013). Effect of pressure, depressurization rate and pressure cycling on the inactivation of Escherichia coli by supercritical carbon dioxide. Food Control, 29, 76-81. https://doi.org/10.1016/j.foodcont.2012.05.068

Singleton, V. L., \& Rossi, J. A. (1965). Colorimetry of total phenolics with phosphomolybdic-phosphotungstic acid reagents. American Journal of Enology and Viticulture, 16, 144-158. http://www.ajevonline.org/content/16/3/144

Smit, Y., Cameron, M., Venter, P., \& Witthuhn, R. C. (2011). Alicyclobacillus spoilage and isolation - a review. Food Microbiology, 28, 331-349. https://doi.org/10.1016/j.fm.2010.11.008

Spilimbergo, S., \& Bertucco, A. (2003). Non-thermal bacteria inactivation with dense CO2. Biotechnology and Bioengineering, 84, 627-638. https://doi.org/10.1002/bit.10783

Tan, T., Cheng, L., Bhat, R., Rusul, G., \& Easa, A. M. (2014). Composition, physicochemical properties and thermal inactivation kinetics of polyphenol oxidase and peroxidise from coconut (Cocos nucifera) water 
obtained from immature, mature and overly-mature coconut. Food Chemistry, 142, 121-128. https://doi.org/10.1016/j.foodchem.2013.07.040

U.S. Department of Health and Human Services and World Health Organization. (2011). Global health and aging. NIH publication number 11-7737.

U.S. Food and Drug Administration. (2001a). United States Food and Drug Administration: 21 Code of Federal Regulations Part 172.133. Dimethyl dicarbonate.

U.S. Food and Drug Administration. (2001b). Report from Institute of Food Technologists. Evaluation and Definition of Potentially Hazardous Foods.

U.S. Food and Drug Administration. (2016). Guidance for Industry: Juice HACCP Hazards and Controls Guidance First Edition; Final Guidance.

Walter, E. H. M., Kabuki, D. Y., Esper, L. M. R., Sant'Ana, A. S., \& Kuaye, A. Y. (2009). Modelling the growth of Listeria monocytogenes in fresh green coconut (Cocos nucifera L.) water. Food Microbiology, 26, 653-657. https://doi.org/10.1016/j.fm.2009.04.003

Wang, C., Chen, Y., Xu, Y., Wu, J., Xiao, G., Zhang, Y., \& Liu, Z. (20130. Effect of dimethyl dicarbonate as disinfectant on the quality of fresh-cut carrot (Daucus carota L.). Journal of Food Processing and Preservation, 37, 751-758. https://doi.org/10.1111/j.1745-4549.2012.00718.x

Xu, Z., Zhang, L., Wang, Y., Bi, X., Buckow, R., \& Liao, X. (2011). Effects of high pressure CO2 treatments on microflora, enzymes and some quality attributes of apple juice. Journal of Food Engineering, 104, 577-584. https://doi.org/10.1016/j.jfoodeng.2011.01.020

Yong, W. J. W. H., Ge, L., Ng, Y. F., \& Tan, S. N. (2009). The chemical composition and biological properties of coconut (Cocos nucifera L.). Molecules, 14, 5144-5164. https://doi.org/10.3390/molecules14125144

Yu, Y., Wu, J., Xiao, G., Xu, Y., Tang, D., Chen, Y., \& Zhang Y. (2013). Combined effect of dimethyl dicarbonate (DMDC) and nisin on indigenous microorganisms of litchi juice and its microbial shelf life. Journal of Food Science, 78, 1236-1241. https://doi.org/10.1111/1750-3841.12215

Yu, Y., Xiao, G., Xu, Y., Wu, J., \& Wen, J. (2014). Effects of Dimethyl Dicarbonate (DMDC) on the Fermentation of Litchi Juice by Lactobacillus casei as an Alternative of Heat Treatment. Journal of Food Science, 79, 947-954. https://doi.org/10.1111/1750-3841.12428

Zhou, L., Wang, W., Hu, X., Wu, J., \& Liao, X. (2009). Effect of high pressure carbon dioxide on the quality of carrot juice. Innovattive Food Science \& Emerging Technology, 10, 321-327.

https://doi.org/10.1016/j.fset.2009.01.002

\section{Copyrights}

Copyright for this article is retained by the author(s), with first publication rights granted to the journal.

This is an open-access article distributed under the terms and conditions of the Creative Commons Attribution license (http://creativecommons.org/licenses/by/4.0/). 